\title{
NOWOCZESNOŚĆ I ZBAWIENIE
}

\author{
MICHAŁ ROGALSKI, PRODUCENCI MARGARYNY? \\ MARIAN ZDZIECHOWSKI I POLSKI MODERNIZM KATOLICKI
}

Tomasz Herbich

Uniwersytet Warszawski

Polski modernizm katolicki nie cieszył się dotychczas dużym zainteresowaniem badaczy. Najważniejszą poświęconą mu pracą była rozprawa Zbigniewa Mikołejki (Mikołejko 1987), przy czym - jak zauważył Michał Rogalski - nawet to studium „zajmowało się sprawą modernizmu katolickiego nie bezpośrednio, lecz w nieco szerszym kontekście katolickiej filozofii kultury przełomu XIX i XX wieku" (Rogalski 2018: 12). To niewielkie zainteresowanie polskim modernizmem katolickim staje się szczególnie wymowne, gdy z jednej strony liczbę poświęconych mu prac porówna się z liczbą rozpraw i analiz dotyczących polskiego mesjanizmu romantycznego jako pewnej postaci filozofii religijnej przynajmniej źródłowo związanej z katolicyzmem (choć pozostającej wobec niego w głęboko ambiwalentnym stosunku) oraz zmierzającej do reformy życia duchowego, społecznego i politycznego, a z drugiej strony gdy zwróci się uwagę na ciągle utrzymujące się zainteresowanie takimi kluczowymi dla polskiej recepcji modernizmu katolickiego twórcami, jak Marian Zdziechowski czy Stanisław Brzozowski. Zwłaszcza o filozoficznych i religijnych poglądach Zdziechowskiego trudno mówić w oderwaniu od zagadnienia modernizmu katolickiego, a przeprowadzone przez Rogalskiego obszerne analizy wydobywające i uwypuklające modernistycznokatolicką wymowę Pesymiz̨mu, romantyzmu a podstaw chrześsijaństwa pozwalają wręcz odzyskać to dzieło dla współczesnej, aktualizującej lektury. Taki wysiłek ponownego odczytania opus ma- 
gnum Zdziechowskiego jest potrzebny także dlatego, że obecnie wydaje się tracić na znaczeniu motyw, który był decydujący dla atrakcyjności intelektualnej autora $W$ ǐji Krasińskiego w latach 80. ubiegłego wieku, następująco scharakteryzowany przez Tomasza Mertę: „Marian Zdziechowski [...] powracał jednak nie tyle jako filozof, subtelny znawca romantyzmu i myśliciel próbujący pogodzić filozofię z wiarą chrześcijańską, ile jako radykalny krytyk współczesności, prorok nadciągającej zagłady. O jego atrakcyjności decydowała także rzucająca się w oczy odmienność rozumienia komunizmu" (Merta 2011: 257). Warto sięgać do Zdziechowskiego jako do wybitnego myśliciela religijnego - a w tym celu należy nie tylko koncentrować się na jego badaniach poświęconych polskiemu romantyzmowi czy na związkach z rosyjskim renesansem religijno-filozoficznym, lecz także na tym, jakie stanowisko zajmował w kluczowych sporach, które toczyły się w Kościele katolickim w jego czasach.

W rozprawie Producenci margaryny? Marian Zdziechowski i polski modernizm katolicki Rogalski uzupełnia tę istotną lukę w badaniach nad polskimi tradycjami intelektualnymi, jaką jest brak syntezy, która docelowo zajmowałaby się polskim modernizmem katolickim. Dowodzi nie tylko - wbrew antymodernistom - że modernizm katolicki w Polsce istniał i nie miał jedynie epizodycznego charakteru, lecz także tego, że odegrał on istotna rolę w dziejach polskiej kultury umysłowej. Warto przy tym podkreślić, że obiektywną prezentację historyczną analizowanego zagadnienia Rogalski umiejętnie łączy z zaangażowaniem w jego rozwiązywanie, czyli w oddawanie sprawiedliwości modernistom. Te dwa wymiary - obiektywizm i zaangażowanie - nie tylko występuja w Producentach margaryny? obok siebie, lecz są ze sobą integralnie związane. Wspólnie tworzą one własny, oryginalny styl autora. Oba dają się usłyszeć w następującej deklaracji: „Działalność historyka filozofii stanowi dla mnie [...] próbę pisania historii znów na nowo, które możliwe jest dzięki niezmiennej dynamice procesu rozumienia. To, co próbowałem osiagnąć w tej pracy, to przekonać czytelnika, że coś takiego jak modernizm katolicki w ogóle się polskiej kulturze przydarzyło. Następnie zaś próbowałem zrozumieć, co się nam tak naprawdę przytrafiło. I o tym jest ta książka" (Rogalski 2018: 18).

Uważny czytelnik Producentów margaryny? bez trudu zauważy, że autor książki jest szczególnie przywiązany do tych wątków modernizmu katolickiego, które można zwięźle scharakteryzować jako „temat i postawę” (Karłowicz 2005: 8) $)^{1}$ - i które w związku z tym mają odniesienie do współ-

${ }^{1}$ Określenie to przejmuję z książki Dariusza Karłowicza Sokrates i inni święci, którą pod wieloma
względami warto skonfrontować z pracą Rogalskiego, rozważanie zagadnień historycznych pro- 
czesności ${ }^{2}$. Jego podejście do analizowanego zagadnienia wyrasta z tradycji hermeneutycznej i realizuje następujący postulat Gadamera: „Muszę uznać roszczenie tradycji nie w sensie samego tylko uznania inności przeszłości, lecz w taki sposób, by miała ona mi coś do powiedzenia. Również to wymaga zasadniczej otwartości. [...] Świadomość efektywnodziejowa [...] pozwala, by tradycja stała się dla niej doświadczeniem, i jest otwarta na wezwanie do prawdy, jakie w niej spotyka" (Gadamer 2013: 492). Tym, co Rogalski odnajduje w tradycji polskiego modernizmu katolickiego, jest właśnie to wezwanie do prawdy, przyjmowane przez niego w warunkach jego czasów, określonych przede wszystkim przez nauczanie II Soboru Watykańskiego. Ma to podwójne znaczenie. Z jednej strony autor Producentón margaryny? jest przekonany, że modernizm katolicki antycypował zagadnienia, które znalazły się w centrum uwagi ostatniego Soboru (Rogalski 2018: 220). Z drugiej strony można wykazać - choć sam Rogalski tego nie czyni - że część poglądów modernistycznokatolickich bez trudu znalazłaby dla siebie miejsce we współczesnej debacie prowadzonej w Kościele katolickim jako jedno z uprawnionych stanowisk lub perspektyw opisu poszczególnych zagadnień. Dotyczy to choćby tego ujęcia wiary, które zostało zaprezentowane w jedynej odnalezionej przez Rogalskiego „pracy stricte teologicznej, którą można zaklasyfikować do nurtu recepcji modernizmu katolickiego w Polsce" (tamże: 183), czyli w studium O akcie wiary ze stanowiska nowożytnej psychologii Jana Ciemniewskiego. Ten ksiądz prowadzący przede wszystkim działalność katechetyczną (tamże: 165) dążył do wykazania, że formalizm religijny, który ujmuje wiarę wyłącznie jako akt intelektualny polegający na „przyjęciu pewnego zespołu twierdzeń objawionych przez Boga i podanych przez Kościół do wierzenia” (tamże: 187), nie uwzględnia „roli jednostkowego podmiotu w procesie wierzenia” (tamże: 188). Chciał zastapić to ujęcie wiary innym, które Rogalski następująco charakteryzuje: „Kiedy Ciemniewski mówi o wierze, chodzi mu więc o będącą konsekwencją określonego nastawienia woli sytuację, w której człowiek nie tylko zdaje sobie sprawę z istnienia Boga i przyjmuje określone konsekwencje tego twierdzenia, ale całe swoje życie - wszystkie czyny, decyzje, pragnienia i plany - kieruje w taki sposób, jaki wynika z jego przekonania o istnieniu Boga i z pragnienia wypełniania tego, co uważa za Bożą wolę" (tamże: 186). Uważna lektura Producentów margaryny? może zresztą prowadzić do

wadzi w niej bowiem do podjęcia kwestii stosunku chrześcijan do takiej kultury, w której centrum duchowym nie znajduje się chrześcijaństwo.

${ }^{2}$ Warto przywołać w tym kontekście ostatnie zdanie książki, które otwiera ją na perspektywę późniejszego trwania omówionych w niej poglądów i postaw: „Jeżeli moderniści katoliccy w Polsce byli, to zapewne doczekali się swoich kontynuatorów i spadkobierców" (Rogalski 2018: 220). 
wniosku, że dowartościowanie indywidualnego podmiotu aktów wiary i jego poszukiwań moralnych stanowi oprócz otwarcia na współczesną cywilizację najważniejszy wątek powracający u różnych przedstawicieli polskiego modernizmu katolickiego. Jest on kluczowy dla Zdziechowskiego (Rogalski zauważa, że ,wizję oczyszczonego modernizmu przedstawiona przez Zdziechowskiego można nazwać zwrotem ku moralności” - tamże: 117), zostaje przejmująco postawiony przez Wysłoucha w chwili jego odejścia z kapłaństwa (tamże: 163) i daje o sobie znać nawet w dowartościowaniu codzienności przez życzliwie przyglądającego się modernizmowi katolickiemu Brzozowskiego (tamże: 205-206).

Pierwsza trudność, z którą musi sobie poradzić badacz modernizmu katolickiego, dotyczy definicji pojęcia. W części rozpoczynającej pracę Rogalski dokonuje istotnych dla dalszych rozważań wyborów terminologicznych i wprowadza ważne rozróżnienia. Rozpoczyna ją od rozdziału, w którym wybiera jedną $z$ czterech występujących w literaturze przedmiotu strategii definiowania modernizmu katolickiego, polegająca na „poszukiwaniu jak najogólniejszej wspólnej definicji modernizmu, aby określić przy jego pomocy wiele rozmaitych stanowisk mieszczących się w obrębie pewnej wspólnej optyki” (tamże: 25), i podaje następującą definicję: „Modernizm katolicki jest wielonurtowym ruchem, dla którego wspólną płaszczyznę stanowi przekonanie o konieczności zbliżenia czy pogodzenia katolicyzmu przełomu wieków XIX i XX ze współczesną mu cywilizacją" (tamże: 26). Następnie autor wyznacza ramy chronologiczne interesującego go zjawiska oraz czyni bardzo ważne spostrzeżenie, zgodnie z którym myślicieli modernistycznych i antymodernistycznych łączy przekonanie, że „świat, współczesność, w której osadzony jest Kościół, znajduje się w kryzysie” (tamże: 30), dzieli ich natomiast opinia na temat tego, jaka powinna być reakcja na ten kryzys (tamże: 31). Rogalski słusznie wskazuje, że wiąże się z tym podstawowe napięcie występujące $\mathrm{w}$ myśli modernistycznokatolickiej, które można wyrazić w pytaniu: „Skoro [...] cywilizacja znajduje się w kryzysie, to czy dobrym pomysłem jest próba wyjścia z niego poprzez inkorporowanie do myśli katolickiej pomysłów filozoficznych i społecznych lub metod naukowych przez tę cywilizację stworzonych?” (tamże: 209). Podobnie złożona jest modernistycznokatolicka ocena ówczesnego stanu życia religijnego. Przełom XIX i XX wieku miałby być momentem, w którym odrodzenie życia religijnego po okresie dominacji pozytywizmu (stwierdzane choćby przez Ignacego Szmidta - tamże: 197) współistnieje z potrzeba znalezienia dla niego nowych podstaw, postulowana w następujących słowach przez Zdziechowskiego: „[...] walą się te podstawy 
rozumowe, na których budowano religię, trzeba nowych podstaw, nowej filozofii i teologii, nowej sterowniczki dla tych najwyższych aspiracyj, »co są potrzebą i żywotem Ducha«" (Zdziechowski 1993 [1914]: 143).

Powróćmy do przyjętej przez Rogalskiego definicji modernizmu katolickiego. Autor Producentón margaryny? podaje następujące argumenty, które maja przemawiać za wybrana przez niego strategią definiowania tego zjawiska: oddaje ona „sprawiedliwość wspólnocie losów modernistycznych”, "pozwala połączyć w jeden wielonurtowy ruch sprzeciw wobec integrystycznej wersji katolicyzmu”, „nie zamazuje różnorodności podstaw, a jedynie szuka ich wspólnej komponenty”, oraz „odpowiada popularnej katolickiej świadomości” (Rogalski 2018: 25). Niezależnie od poprawności i - jak sądzę - trafności tej argumentacji należy zauważyć, że wybór tego sposobu definiowania modernizmu katolickiego pociaga za sobą zarówno pewne konsekwencje, jak i istotne trudności. Najważniejszą konsekwencja jest ta, że ze względu na przyjętą ogólną definicję, która ma znaleźć wspólną podstawę dla nieraz odległych od siebie fenomenów intelektualnych, Rogalski zakłada, że w każdym z omawianych przez niego zagadnień dochodzi do głosu jedno i to samo dążenie - każda sprawa staje się dla niego „frontem większej bitwy o (krytyczne) otwarcie na współczesną cywilizację" (tamże: 115). Nawet jeżeli uznamy (a sądzę, że można się zgodzić z takim poglądem), że w przypadku samych modernistów katolickich taka interpretacja może zostać przekonująco obroniona, to jednak sprawa staje się znacznie bardziej skomplikowana, gdy zapytamy o to, czy przeciwstawną motywację da się tak samo bezwarunkowo przypisać przeciwnikom modernistów. Czy moglibyśmy uznać - a dychotomiczny obraz, w którym po jednej stronie znajdują się moderniści, a po drugiej antymoderniści, kazałby konsekwentnie taki pogląd przyjąć - że motywacja stojąca na przykład za antymodernistyczną krytyką filozofii Immanuela Kanta daje się w każdym przypadku sprowadzić do zamknięcia na współczesną cywilizację? Negatywna odpowiedź na to pytanie prowadzi do istotnego wniosku: przyjęta przez Rogalskiego perspektywa opisu modernizmu katolickiego pociaga za soba schematyczne ujęcie ich przeciwników. Co jednak istotne, badacz zdaje sobie z tego sprawę, skoro stwierdza, że polski antymodernizm to „zjawisko pod wieloma względami odrębne i wymagające innego podejścia niż przyjęte w tej pracy" (tamże: 15), i przyznaje się do potraktowania go w sposób „bardzo użytkowy i skrótowy” (tamże: 219).

Należy również zdać sprawę z trudności, które mogą wynikać z przyjęcia takiego sposobu rozumienia modernizmu katolickiego. Ma on u swych źródeł punkt widzenia właściwy dla krytyków modernizmu, zaprezento- 
wany po raz pierwszy w encyklice Piusa X Pascendi dominici gregis. Jest to ważne nie tylko dlatego, że - jak w pracy niejednokrotnie zauważa Rogalski - ujęcie to łączy nurty, które istotnie się różnią (według autora recenzowanej publikacji etykieta „modernizmu katolickiego” została „spreparowana przez Piusa X i jego współpracowników na określenie bardzo różnorodnych prób reformy czy otwarcia rzymskiego katolicyzmu” - tamże: 216), lecz także z tego powodu, że prowadzi ono do odtworzenia założonego w ujęciu papieskim dualizmu. O ile jednak myślenie w kategoriach stanowczej opozycji jest w pełni zasadne wtedy, gdy modernizm uznaje się za potężną herezję przeciwstawną wobec ortodoksji, o tyle nie daje się ono uzasadnić, gdy nie zakłada się tak jednoznacznego wartościowania (czyli potępienia albo modernizmu, albo antymodernizmu ${ }^{3}$ ). Ta wynikająca z przyjętej strategii definiowania zjawiska modernizmu katolickiego trudność grozi tym, że odkrywany w drodze badań nad modernizmem katolickim pluralizm polskiego katolicyzmu przełomu XIX i XX wieku ulegnie redukcji do postaci dychotomii. Można jednak tej negatywnej konsekwencji zapobiec poprzez staranną i przede wszystkim oddzielnie prowadzona analizę poglądów i postaw zajmowanych przez poszczególnych modernistów, co de facto uzupełnia przyjętą strategię opisu modernizmu o najistotniejsza zaletę jednego z odrzuconych podejść, akcentującego właśnie różnorodność modernizmów katolickich. Tak postąpił Rogalski w trzeciej części pracy, w której prezentuje sylwetki i poglądy poszczególnych przedstawicieli polskiego modernizmu katolickiego (Maurycego Straszewskiego, Izydora Kajetana Wysłoucha, Jana Ciemniewskiego, Ignacego Szmidta, a także początkowo bliskiego liberalnemu katolicyzmowi, a potem zdecydowanie antymodernistycznego Ignacego Charszewskiego, oraz przygladających się modernizmowi katolickiemu spoza Kościoła Stanisława Brzozowskiego i Ignacego Radlińskiego), a także w drugiej, najobszerniejszej części, wszechstronnie omawiającej związki Mariana Zdziechowskiego z modernizmem katolickim. Uważny czytelnik książki bez trudu zauważy, że poświęcone tym bohaterom procesu recepcji modernizmu katolickiego w Polsce analizy ukazuja pełne spektrum postaw: od pozbawionego konkretnych postulatów, lecz wyrażającego jedynie ogólne reformatorskie na-

\footnotetext{
${ }^{3}$ Dlatego jedyną perspektywą, która uzasadniałaby odtworzenie takiego dualizmu w pracy przychylnej modernizmowi, jest ta, którą przyjmuje Ignacy Radliński. To nie przypadek, że mógł on pozytywnie wypowiadać się o skutka ch encykliki Piusa X (co wydaje się paradoksalne, jest jednak całkowicie konsekwentne): „Nie ma więc [według Radlińskiego - T.H.] mowy o pogodzeniu wiary z wiedzą, można jedynie porzucić wiarę na rzecz jej doskonalszej postaci, a ten doniosły krok w dobrą stronę umożliwił modernistom Pius X, pokazując, że w katolicyzmie nie ma miejsca na sięganie do zdobyczy myślowych cywilizacji” (Rogalski 2018: 197).
} 
stawienie Straszewskiego, przez formułującego takie postulaty Zdziechowskiego, aż do radykalnego Wysłoucha, którego zaangażowanie w reformę katolicyzmu doprowadziło aż do zerwania z Kościołem (tamże: 176).

Poprawne posługiwanie się szeroką definicją modernizmu katolickiego, konieczna - trzeba tu przyznać rację autorowi - ze względu na nieokreśloną, heterogeniczną naturę zagadnienia, sprawia, że niezbędna staje się ciągła uważność, aby nie włączać do tego nurtu zbyt wielu zjawisk. Wystarczy niewielkie tylko nadużycie, aby choćby Wincentego Lutosławskiego, słusznie przez Rogalskiego wyłączonego z grona modernistów katolickich, uznać za przedstawiciela tego nurtu. W takiej roli występował on w literaturze antymodernistycznej, mimo że źródła jego światopoglądu są wyraźnie odmienne (tamże: 157). Z kolei przykład twórczości Wysłoucha z lat 1908-1910 pokazuje, że szeroka definicja modernizmu katolickiego zakłada istnienie warunku, bez którego spełnienia nie można uznać danego autora za przedstawiciela tego nurtu. Jest nim dążenie do reformy katolicyzmu (tamże: 163-164), zakładające utrzymywanie związku z Kościołem, a nie - dokonane na podstawie własnej decyzji odejście od niego.

Jeżeli do zobrazowania wewnętrznego pluralizmu polskiego modernizmu katolickiego posłużyła Rogalskiemu analiza poglądów i postaw poszczególnych bohaterów jego recepcji w Polsce, to jego rozpiętość tematyczną autor ilustruje poprzez określenie czterech sporów, w których moderniści uczestniczyli. Dotyczyły one historyczności (ten spór utożsamiany jest przez Rogalskiego z zagadnieniem historyczno-krytycznej egzegezy tekstów biblijnych) i dogmatów (uznania ich zależności od czasu) oraz jednostki (czyli miejsca indywidualnego doświadczenia w rozumieniu wiary) i wielości (postawy dopuszczającej pluralizm rozwiązań) (tamże: 33-45). Warto zwrócić uwagę, że pierwsze dwa spory można zredukować do jednego - oba one dotycza bowiem stosunku do historii i do wpisanego w nią (a także w inne dyscypliny naukowe) potencjału genetycznego (i zarazem krytycznego) wyjaśniania zjawisk religijnych, który w odniesieniu do dorobku Newmana został silnie zaakcentowany przez Brzozowskiego (Brzozowski 1990: 437-440).

Choć jak wspomniałem, w Producentach margaryny? autor świadomie nie podejmuje próby charakterystyki polskiego antymodernizmu, nie może zupełnie abstrahować od niego, co więcej - musi jakoś (nawet jeżeli w sposób niezgłaszający pretensji do zupełności ani ostateczności) określić jego racje w sporze $z$ modernizmem. Jedyne istotne zastrzeżenie, które zgłaszam pod adresem zaproponowanej przez Rogalskiego syntezy polskiego modernizmu katolickiego, dotyczy właśnie sposobu, w jaki ujmuje on racje jego 
przeciwników. Dobrego przykładu może dostarczyć fragment, w którym autor omawia sformułowaną przez Jana Rostworowskiego krytykę Pestis perniciosissima Zdziechowskiego. Rogalski podsumowuje stanowisko Rostworowskiego stwierdzeniem: „Znowu więc możliwość rozmowy zostaje zablokowana przez konieczność obstawania przy tym, co obiektywne i prawdziwe" (Rogalski 2018: 80-81). Trudno jednak nie uznać, że obstawanie przez Rostworowskiego przy obiektywizmie prawdy i wynikającym z niej sposobie uprawiania teologii nie daje się sprowadzić do „zablokowania możliwości rozmowy" czy do prowadzenia teologii w jakąś stronę jednowymiarową i homogeniczną, lecz odnosi spór na poziom fundamentalny. Jeżeli bowiem objawienie prawdy w Chrystusie ma mieć charakter powszechny, to bez uznania obiektywizmu prawdy trudno zrozumieć, czym ta powszechność miałaby być. Stawką sporu jest tu zatem zbawienie - dla obu stron. To troska o nie prowadzi zarówno do podejmowania działań na rzecz zbliżenia Kościoła i świata, jak i do napiętnowania określonych poglądów jako odwodzących od pobożności. „Pobożność [...] zostaje złamana i splamiona i nie ustrzeże się uszczerbku, gdy fałsz przedostaje się do duszy" - pisał w II wieku po Chrystusie święty Ireneusz z Lyonu, po czym dodawał, że heretycy są tymi, którzy „,psuja tych, którzy przyjmuja truciznę ich nauki” (Ireneusz z Lyonu 1997: 22-23). W kontrowersji antymodernistycznej strategia znana z wcześniejszej historii chrześcijaństwa została zastosowana do nowych zjawisk, jakościowo różnych od tych, które znał Ireneusz, oraz doszło do jej konfrontacji z dynamicznie rozwijająca się nowoczesnością i jej stylem - tym samym, z którym konfrontowali się zwolennicy lub sympatycy liberalnego katolicyzmu, stylem następująco charakteryzowanym przez Brzozowskiego w jednym z jego listów: „Nie przypuszczałem, że Wiedeń zrobi na mnie tak poważne wrażenie. Zdumiewający jest Ś-ty Szczepan na tle tak całkowicie nowoczesnego miasta. [...] Powtarzam więc, że jako odpowiedź nowoczesnego Wiednia S[z]czepanowi, hotele, kawiarnie, dworce kolei żelaznej - tj. nasz styl. Zupełnie odpowiada w gruncie rzeczy naszemu życiu. Jesteśmy tymczasowi. Ciagnące się poprzez wieki pis-aller ludzkości, niezbędne tylko dla zachowania ciagłości” (Brzozowski 1970, I: 102-103).

Rezultat tej konfrontacji antymodernistycznej strategii z nowoczesnością nie mógł być jednoznaczny. Zdziechowski trafnie wykazywał słabość stanowiska Rostworowskiego, gdy przenosił punkt ciężkości na kwestię sposobu dochodzenia do wiary i istnienia w niej również wymiaru niepoddającego się logice teologicznego racjonalizmu: „Nikt oczywiście, żaden nawet najfanatyczniejszy teolog nie odważyłby się twierdzić, że Objawie- 
nie stoi tylko na rozumowym gruncie, ale wraz z uznaniem, że stoi na sil ny m rozumowym gruncie, rodzi się dążność do racyonalizowania religii i do zapoznawania moralnego czynnika wiary, który nie bez odcienia pogardy nazywaja sercem i traktują jako objaw sentymentalizmu" (Zdziechowski 1993 [1914]: 260). Temu samemu zagrożeniu mógł jednak zdaniem Zdziechowskiego podlegać także modernizm katolicki, a ta możliwość zrealizowała się w przypadku modernistycznej egzegezy biblijnej: „Nauka i krytyka zaprowadziły niektórych przedstawicieli i kierowników prądu modernistycznego tak daleko, że utracili zmysł chrześcijański, gorzej jeszcze, zmysł religijny" (tamże: 407) ).

W tym kontekście warto nieco uwagi poświęcić metaforze użytej w tytule książki Rogalskiego. Metafory nieraz poddają się przeciwstawnym interpretacjom, przez co staja się mieczami obosiecznymi. Jest tak z przejętym przez autora Producentów margaryny? z mowy biskupa Paula Wilhelma von Kepplera określeniem modernizmu katolickiego jako „,katolicyzmu margarynowego". Wypowiedź Kepplera wpisywała się w ówczesny kontekst, w którym margaryna była przedmiotem sporu (Rogalski 2018: 7-10). Zarówno ona, jak i liberalny prąd w katolicyzmie były ,wytworami procesu gwałtownej i wielowymiarowej modernizacji cywilizacji zachodniej przełomu XIX i XX wieku” (tamże: 215). Jak stwierdza Rogalski, choć „intencja Kepplera było niewątpliwie jednoznaczne potępienie dążeń reformatorskich”, metafora przez niego użyta „okazuje się [...] o wiele bardziej wieloznaczna niż mógłby to przewidzieć jej autor” (tamże: 10). Margaryna nie musiała bowiem być odbierana jako zagrożenie, lecz można ją było równie dobrze postrzegać jako zdrową konkurentkę dla masła.

W Producentach margaryny? Rogalskiemu udaje się odwrócić znaczenie tej metafory - dowartościować wkład, jaki do rozwoju katolicyzmu i polskiej kultury umysłowej wnieśli ci, którzy byli odpowiedzialni za uformowanie i krzewienie „katolicyzmu margarynowego” (tamże: 219-220). Zastanówmy się jednak, czy metafora ta nie może podlegać ponownemu odwróceniu, które przywraca ją Kepplerowi. W cytowanej przez Rogalskiego wypowiedzi na temat masła sztucznego (margaryny) czytamy, że „zastępuje ono w zupełności masło krowie w przygotowaniu potraw" (tamże: 9). Czy jednak nasze doświadczenia kulinarne pozwalają się nam z tą tezą zgodzić? Czy naprawdę żadnej różnicy nie czyni to, czy używamy masła, czy margaryny? Może zatem podobnie rzecz ma się, gdy chodzi o rywalizację

\footnotetext{
${ }^{4}$ Porównaj także fragment recenzowanej książki poświęcony wcześniejszemu ujęciu tego zagadnienia w opublikowanym po rosyjsku tekście Zdziechowskiego Ruch modernistyczny w Kościele rzymsko-katolickim (Rogalski 2018: 96-97).
} 
zwolenników katolickiej ortodoksji z tymi, których określili oni zbiorczym mianem modernistów katolickich?

Udzielenie odpowiedzi na to pytanie znacznie przekracza ramy recenzji. Niezależnie od tego, jaka ona będzie, trzeba zgodzić się z autorem Producentón margaryny?, że „katolicyzm margarynowy” nie tylko się nam przydarzył, lecz także odegrał istotną rolę w dziejach polskiej kultury umysłowej. Należy mieć nadzieję, że pierwsza synteza polskiego modernizmu katolickiego, która docelowo się nim zajmuje, wpłynie na dalszy rozwój tego obszaru badań. Jednym z zagadnień, które powinno zostać podjęte w toku dalszych prac (oprócz kluczowej sprawy, jaka jest stworzenie podobnej syntezy poświęconej polskiemu antymodernizmowi), powinna być kwestia związków ideowych występujących między naszym modernizmem katolickim a myśla religijna polskiego romantyzmu. O potrzebie podjęcia tego zagadnienia świadczy nie tylko sam fakt, że modernizm katolicki zyskał uznanie autorów tak ważnych dla recepcji romantyzmu polskiego i jego filozofii na początku XX wieku, jak Zdziechowski czy Brzozowski. To współwystępowanie obu zainteresowań nie jest bowiem pozbawione dostrzegalnych konsekwencji. Rogalski zauważa, że namysł nad reformą katolicyzmu służył Zdziechowskiemu nie tylko do celów uniwersalistycznych, lecz także lokalnych, czyli do refleksji nad polskością, oraz że wiązał się on ze zmianą jego stosunku do Towiańskiego i towianizmu (tamże: 87$88)^{5}$. Z kolei w przypadku Brzozowskiego zainteresowanie modernizmem katolickim łączyło się w czasie ze studiowaniem romantyzmu angielskiego, co stanowiło ostatni akt jego zmagań z romantyczną spuścizną (Bielik-Robson 2007: 297-315). Niepozbawiony znaczenia może być też fakt, że w artykule o Loisym i zagadnieniach modernizmu katolickiego Brzozowski zestawił filozofię Bergsona (będącą istotnym źródłem inspiracji dla części modernistów) ze światopoglądem wyrażonym w prelekcjach paryskich Mickiewicza (Brzozowski 1990: 446-447). Dokonane przez Straszewskiego powiązanie reformy katolicyzmu z koncepcja religii przyszłości, która ma być zinstytucjonalizowaną ideą nadającą cel i kierunek społeczeństwu, wykazuje z kolei zbieżność $z$ romantycznym mesjanizmem. Podjęcie badań nad związkami ideowymi występującymi między myślą religijną polskiego romantyzmu a polskim modernizmem katolickim mogłoby z jednej strony przyczynić się do określenia specyfiki tego ostatniego, a z drugiej strony pozwoliłoby umieścić go w nurcie polskiej filozofii religijnej jako jedna

\footnotetext{
${ }^{5}$ Związkom między nowymi prądami w Kościele a nauką Towiańskiego poświęca Zdziechowski ostatni fragment Pesymizmu, romantyzmu a podstaw cbrześsijaństwa. Por. Zdziechowski 1993 [1914]: $412-420$.
} 
z jej najważniejszych formacji historycznych. Stworzona przez Michała Rogalskiego synteza polskiego modernizmu katolickiego przynosi przełom w badaniach nad tym fenomenem intelektualnym oraz czyni możliwym dalsze ich rozwijanie we wskazanym i w innych kierunkach.

Bibliografia:

/// Bielik-Robson A. 2007. Syndrom romantyczny albo przeczucie nowoczesności czerpane z lektury angielskich romantyków, [w:] S. Brzozowski, Gtosy wśród nocy. Studia nad przesileniem romantycznym kultury europejskiej, Wydawnictwo Krytyki Politycznej, s. 297-315.

/// Brzozowski S. 1970. Listy, t. I: 1900-1908, red. M. Sroka, Wydawnictwo Literackie.

/// Brzozowski S. 1990. Alfred Loisy i zagadnienia modernizmu katolickiego, [w:] tegoż, Idee. Wstep do filozofii dojrzatości dziejowej, Wydawnictwo Literackie.

/// Gadamer H.-G. 2013. Prawda i metoda. Zarys hermenentylki filozoficænej, tłum. B. Baran, Wydawnictwo Naukowe PWN.

/// Ireneusz z Lyonu. 1997. Wyktad nauki apostolskiej, tłum. W. Myszor, Wydawnictwo WAM.

/// Karłowicz D. 2005. Sokrates i inni święci. O postawie starożytnych chrzéscijan wobec rozumu i filozofii, Fronda, Ośrodek Myśli Politycznej.

/// Merta T. 2011. Wracajac do Zdriechowskiego, [w:] tegoż, Nieodrowność konserwatyzmu. Pisma wybrane, red. T. Stefanek, Teologia Polityczna-Muzeum Historii Polski, s. 257-264.

/// Mikołejko Z. 1987. Katolicka filozofia kultury w Polsce w epoce modernizmu (1895-1918), Państwowe Wydawnictwo Naukowe.

/// Rogalski M. 2018. Producenci margaryny? Marian Zdriechowski i polski modernižm katolicki, Universitas.

/// Zdziechowski M. 1993 [1914]. Pesymizm, romantyzm a podstawy chrześcijaństwa, t. II, IFiS PAN. 
/// Tomasz Herbich - wykładowca w Instytucie Filozofii Uniwersytetu Warszawskiego. Stały współpracownik „Teologii Politycznej”. Specjalizuje się w historii filozofii polskiej i rosyjskiej oraz w teologii biblijnej. Opublikował dwie książki: Pragnienie Królestwa. August Cieszkowski, Mikołaj Bierdiajew i dwa oblicza mesjanizmu (Teologia Polityczna, 2018) oraz Teologia

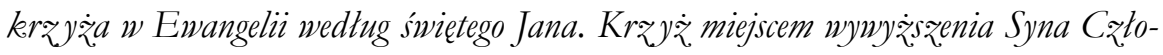
wieczego (Kontrast, 2019). Publikował między innymi w następujących czasopismach: „Teologia Polityczna”, „Kronos”, „Rocznik Historii Filozofii Polskiej”, „Przegląd Filozoficzny”, „Filo-Sofija” oraz „Słowo Krzyża”. W 2017 roku otrzymał Stypendium Cieszkowskiego na realizację projektu badawczego „Filozofia polskiego romantyzmu i rosyjski renesans religijno-filozoficzny w perspektywie porównawczej”.

ORCID: https://orcid.org/0000-0003-3552-3867

E-mail: t.herbich@gmail.com 